LA-UR -82-467

$$
L \wedge-U[:-\varepsilon 2-467
$$

LLLi2 008176

TITLE

AUTHOA(S)

BHBMITTED YO

\section{F.V. Mason}

G. Bowman
REACTIONS FOR IMPROVING EFFICIENCIES IN THERMOCHEMICAL CYCLES RELATED TO THE SULFUR DIOXIDE-IODINE PROCESS

World Energy Conference IV, 13-17 June 1982, Pasadena, CA and to be published in the Proceedings.

c. 1 

REACTIONS FOR IIPROVIHG EFFICIENCIES IN THERMOCHEMICAL
CYCLES RELATED TO THE SULFUR DIOXIDE-IODINE PROCESS

\author{
C. F. V. Mason and M. G. Bowman \\ Chemistry Materials Division \\ Los $A 1$ amos National Laboratory \\ Los Alamos, M 87545
}

\begin{abstract}
A modification of the sulfur dioxide-lodine cycle which uses magnesium oxtde, magnesium sulfite and magneslum lodide is examined with particular emphasis on decraasing the amount of water employed and thereby increasing the efficiency. The key reaction is that of lodine with magnesium oxide and magnesium sulfite hexahydrate with no additional water. Th1s produces $77 \%$ of the total possible sulfate as well as magneslum lodide, hydrogen lodide and hydrogen at $523 \mathrm{~K}$. The. effictency of this cycle varies between $58 \%$ and 39 ; depending on the amount of heat that can be recovered. This is the first example of a cycle where there is no large energy burden due to evaporation.
\end{abstract}

\title{
KEYHORDS
}

The rmochemical hydrogen, sulfur dioxide-lodine cycle, magnesium oxtde, magnestum sulfite, magnestum lodide, magnestum sulfate, hydrogen todide.

\section{INTRODLCTION}

The concept of hydrogen production through splitting water into hydrogen and oxygen by means of several chemical reactloris with acconpanying recyciling of all the Internediates has been studied for some years (Funk and Reinstrom, 1966). A] though many sucil processes nave been experimentally verlfied (Besenbruch and co-workers, 1980) and some closed-loop systems are in operation (Van Velzen and Langenkamp, 1980), the effictency of such processes is usually of the order of $40-50 \%$.

One recurring problem whlch decreases the efficlency of all suggested thermochemical processes centers around the need for drying aqueous solutions. This paper considers the relationship between evaporation and efficiency and examines experimentally an adaptation of the sulfur dioxide-fodine cycle where little water needs to be evaporated or condensed.

\footnotetext{
TWork completed under the auspices of the US Department of Energy, Office uf Bastic Energy Sclences, Diviston of Chemical Sciences
} 
If we consider a thermal efficiency (or figure of merit) of $40 \%$ to be the lower linit of practicality of a thermochemical hydrogen producing process, then the maximum nount of heat available is $715 \mathrm{~kJ}(286 / 0.4)$. Each mole of water evaporatively removed requires $44 \mathrm{~kJ}$ of heat. Thus we can plot the heat required to remove $n$ moles of water expressed as a percentage of the maximum heat permitted $(715 \mathrm{~kJ})$ against $n$. This 15 shown in $F i g .1$. At some other stage in the cycle, this water will be recondensed releasing an equivalent amount of heat wich may be partially applied to the evaporation step, and is also shown in Fig. I as a percentage of the heat recovered. This figure clearly fllustrates the large percentage of the avallable heat utilized evaporatively. Thus when none of the heat is recovered, $18 \%$ of the available heat is used to Evaporate 3 mules of water and when $75 \%$ of the heat is recovered, this same heat will remove 12 moles of water. In general, therefore, there is an upper limit on the amount of water which can be used, the exact value of which will depent. on the sperifics of a cycle.

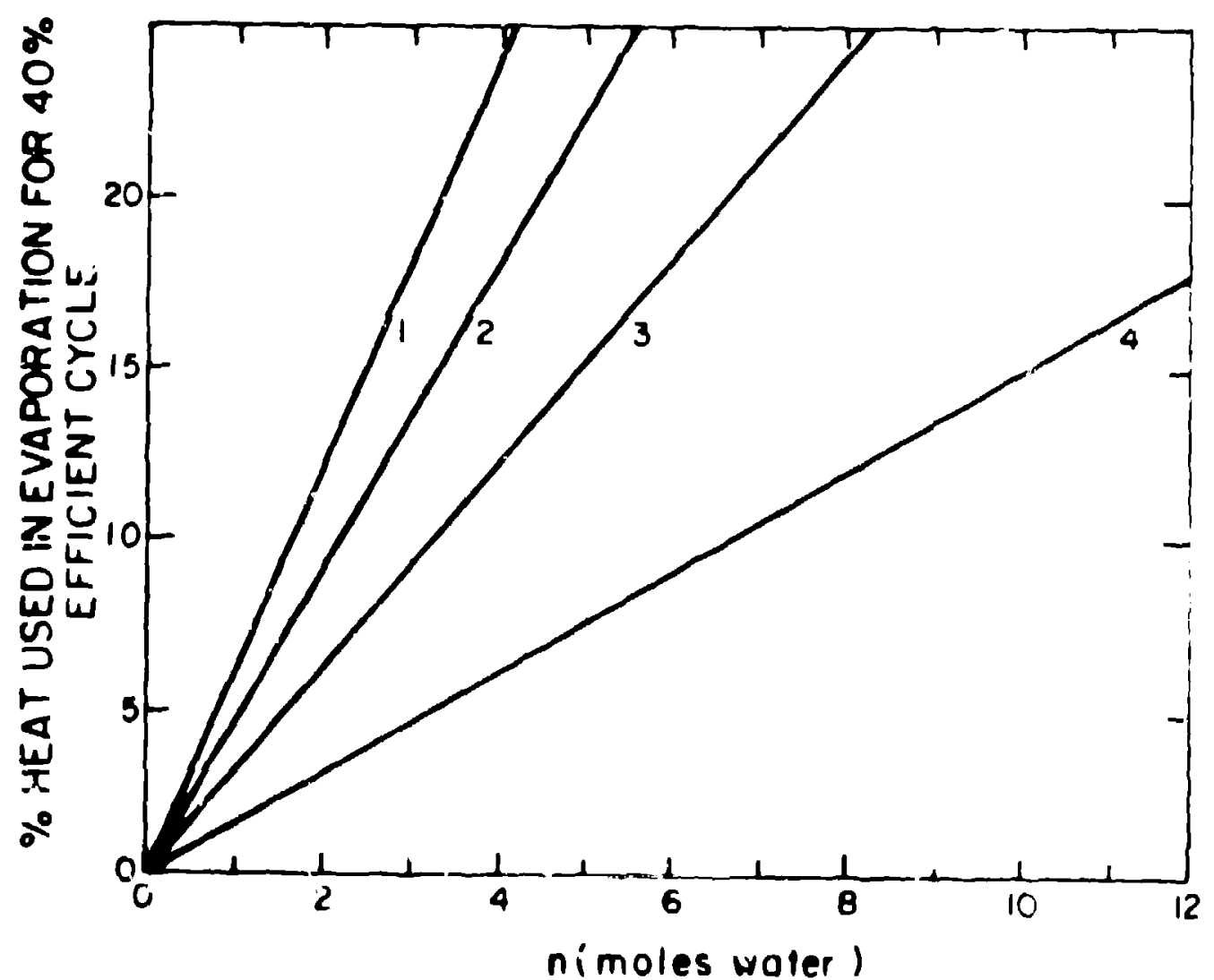

Fig. 1. Heat required to remnve $n$ moles of water as a percentage of the maximum heat permitted for dif ferent percentages of heat recovered, $10 \%, 225 \%$. ? 50\%, 4 75\%. 
The specific cycle studied here can be summarized in the following way:

$$
\begin{aligned}
\mathrm{MgO}_{2}+\mathrm{SO}_{2} & \rightarrow \mathrm{MgSO}_{3} \\
\mathrm{MgO}+\mathrm{MgSO}_{3}+\mathrm{I}_{2} & \rightarrow \mathrm{MgSO}_{4}+\mathrm{MgI}_{2} \\
\mathrm{MgI}_{2}+\mathrm{H}_{2} \mathrm{O} & \rightarrow \mathrm{MgO}_{2} \mathrm{HI} \\
2 \mathrm{HI} & \rightarrow \mathrm{H}_{2}+\mathrm{I}_{2} \\
\mathrm{MgSO}_{4} & \rightarrow \mathrm{MgO}^{2} \mathrm{SO}_{2}+1 / 2 \mathrm{O}_{2}
\end{aligned}
$$

$$
\mathrm{H}_{2} \mathrm{O} \rightarrow \mathrm{H}_{2}+1 / 2 \mathrm{O}_{2}
$$

It was chosen because it nffers the possibility of overcoming the drying and separation steps of the $\mathrm{SO}_{2} / I_{2}$ cycle:

$$
\begin{aligned}
\mathrm{SO}_{2}+\mathrm{I}_{2}+2 \mathrm{H}_{2} \mathrm{O} & \rightarrow \mathrm{H}_{2} \mathrm{SO}_{4}+2 \mathrm{HI} \\
2 \mathrm{HI} & \rightarrow \mathrm{H}_{2}+\mathrm{I}_{2} \\
\mathrm{H}_{2} \mathrm{SO}_{4} & \rightarrow \mathrm{H}_{2} \mathrm{O}+\mathrm{SO}_{2}+1 / 2 \mathrm{O}_{2}
\end{aligned}
$$

which has been extensively studied at General Atomic (Norman and co-workers, 1980). Sulfates, in general, are identifled (Bowran, 1980) as having thermal decomposition characterisitcs which are sultable for themochemical processes. Finally, the magnesium cation was chosen since Mgl 2 hydrolyzes readily. The other more promising metal cations for this type of cycle are La and Ti. IMason and Bowrian, 1981 a).

\section{THE CYCLE}

The cycle is shown in a diagramatic form in Fig. 2 and can be seen to be conceptually simple. All the solid components are cycled between room temperature and $1350 \mathrm{~K}$ with no separations and minimal drying.

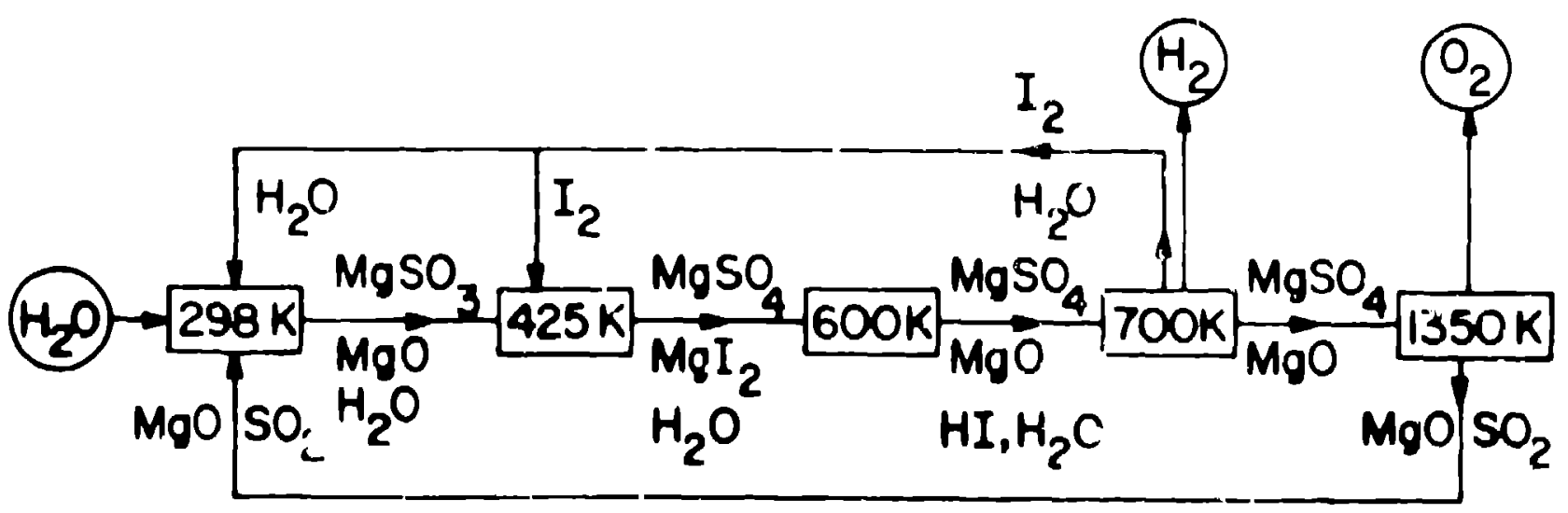

Fig. 2. Schematic Representation of the $\mathrm{MgSO}_{3} / \mathrm{I}_{2}$ cycie. 
From our previous studies it is known that the reaction represented by equ. (1) will only take place in the presence of water and also that reaction (2) is fast and quantitative in dilute aqueous solution (Mason and Bowman, 1980). The hydrolysis of $\mathrm{MgI}$, reaction (3) readily happens in the presence of excess water. The thermal decomposition of $\mathrm{HI}$, reaction (4) occurs in many cycles and has, correspondingly, been studied often (e.g. Takemori, 1978). Finally, the thermal decomposition nf $\mathrm{MgSO}_{4}$ occurs quantitatively, albeit slowly, at 1350 $K$, but can be cataly, by $\mathrm{Fe}_{2} \mathrm{O}_{3}$ (Lau, Cubbiclotti and Hildenbrand, 1977). This decomposition has so $b$-en suggested as part of a thermal energy storage system by reversible chel. cal reactions (Ducarrior. Tmar and Bernard, 1980).

The modynamically the cycle an be written in the following form where $x$ and $y$ represent the mole amounts o1 water necessary for fast quantitative reaction $y$ ields and square brackets denote nonreactive and noninterfering compunents:

$$
\begin{aligned}
& 2 \mathrm{MgO}(\mathrm{s})+\mathrm{SO}_{2}(\mathrm{~g})+\times \mathrm{H}_{2} \mathrm{O}(1) \stackrel{29 \mathrm{BK}}{\rightarrow} \mathrm{HgSO}_{3} \cdot \mathrm{yH}_{2} \mathrm{O}(\mathrm{s})+ \\
& (x-y) \mathrm{H}_{2} \mathrm{O}(1)+\mathrm{MgO}(\mathrm{s})
\end{aligned}
$$

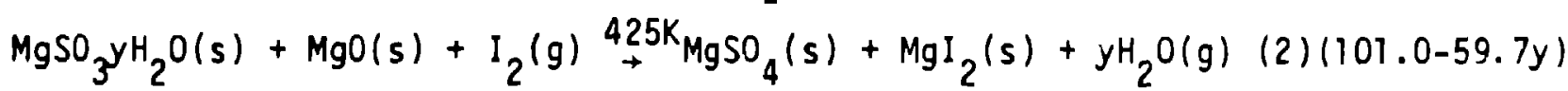

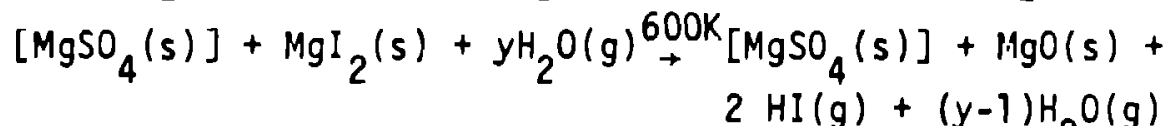

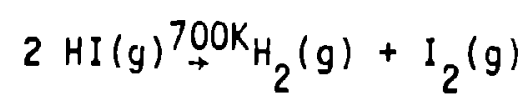

$$
\begin{aligned}
& \mathrm{MgSO}_{4}(\mathrm{~s})+[\mathrm{MgO}(\mathrm{s})] \stackrel{350 \mathrm{~K}}{\rightarrow} 2 \mathrm{MgO}(\mathrm{s})+\mathrm{SO}_{2}(g)+1 / 2 \mathrm{O}_{2}(g)(5)+390.1 \\
& (y-1) \mathrm{H}_{2} \mathrm{O}(g) \stackrel{375 K}{\rightarrow}(y-1) \mathrm{H}_{2} \mathrm{O}(1) \\
& \Delta \mathrm{H}_{298}^{0} \mathrm{~kJ} \\
& \text { (1) }-(109.6+15.7 y) \\
& \text { (3) }+59.8 \\
& \text { (4) }+70.4 \\
& \text { (6) }-(y-1) 44.0
\end{aligned}
$$

The noninterference has been shown to be valid since reaction (2) has been carried out in solution and the products slowl $y$ heated to $1400 \mathrm{~K}$. Thus, after evaporation, a thermogravimetric curve can be interpreted as going through the solid products $\mathrm{MgI}_{2} \cdot 8 \mathrm{H}_{2} \mathrm{O}, \mathrm{MgSO}_{4} \cdot \mathrm{H}_{2} \mathrm{O}, \mathrm{Mg}(\mathrm{OH}) \mathrm{I}, \mathrm{it}_{2} \mathrm{O}, \mathrm{Mg}_{2}(\mathrm{OH})_{3} \mathrm{I}, \mathrm{MgSO}_{4}$

and finally to MgO exclusively (Mizuta and co-workers, 1980).

The thermodynamic data is calcu?ated from tables in two source books (Parker Wagman and Evans, 1971; Weast, 1974) with the assumption miade that the heat associater with each water of hydration is the same. The value of $y$, the number of moles of water which must be evaporated affects the efficlency greatly. The value of $x$, the number of moles of water remaining as liquid, is inuch less significant since $\mathrm{MgSO}_{3}$ is relatively insoluble $(1.25 \mathrm{~g} / 100 \mathrm{cc})$ anci the refore can be separated by flitration from a saturated solution and necessitates no evaporation except for occluded water.

Figure 3 shows the change in efficiency (defined as $\mathrm{AH}_{298} / 5+$ ve $\mathrm{AH}_{298}$ cycie) as a function of $y$ for three different percentages $(100 \%, 50 \%, 0 \%)$ of heat recovered from reactions $(2)$ and $(6)$. No heat can be recovered from reaction (1) since it occurs at room temperature.

One may note that there is an inftial sharp decline in efficlency when some heat is recovered, but with no heat recovery, the efficiency does not change due to the endothenicity of reaction 2 when $y=1.7$. Even though is is clear that the highest effictencies occur in the absence of water. it is known experimientally that $\mathrm{SO}_{2}$ does not react with $\mathrm{MgO}$ in the absence of water. Therefore we examined the value of $x$ in reaction (1). 


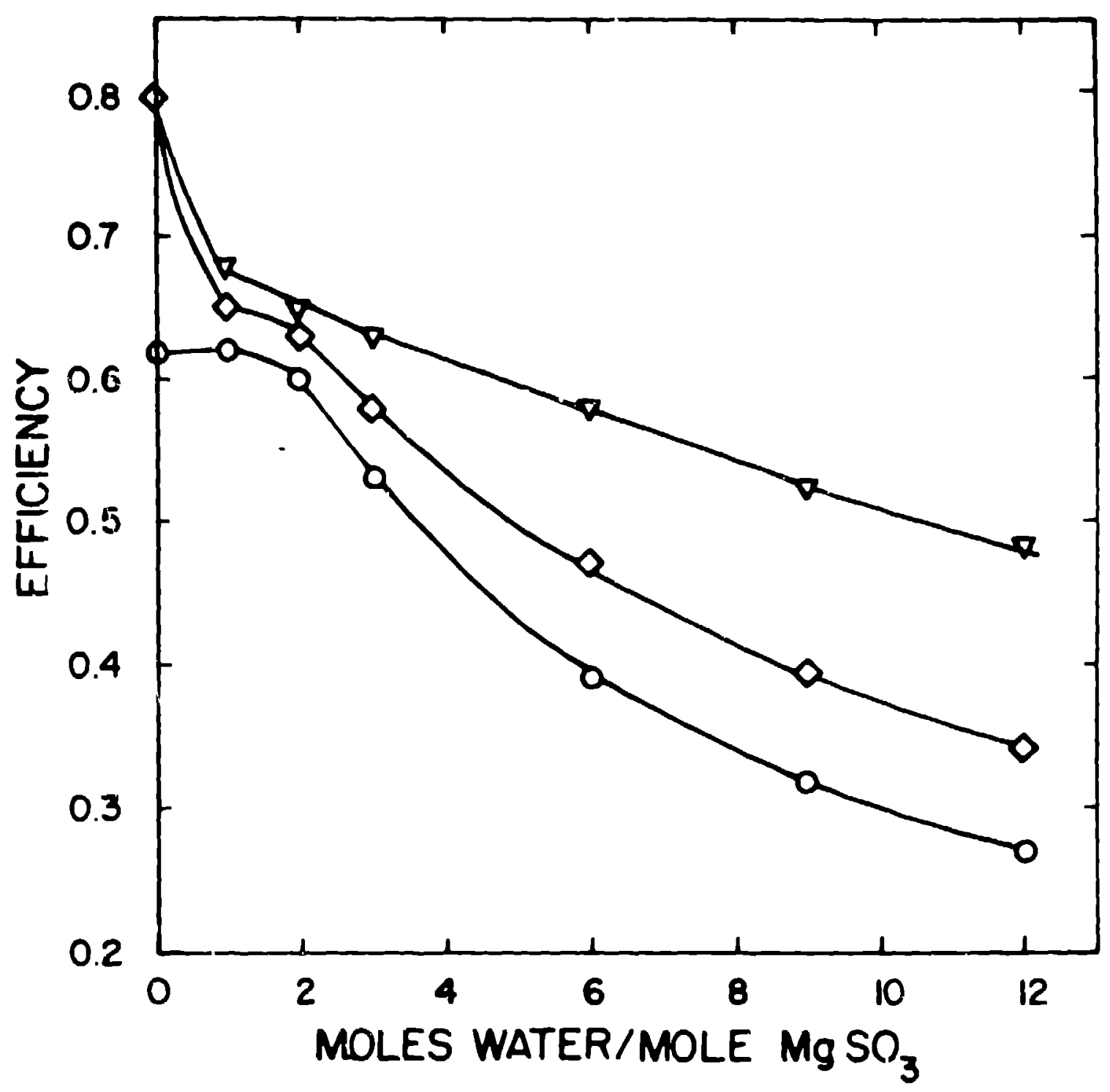

Fig. 3. The effect of the mole ratio of $\mathrm{H}_{2} \mathrm{O} / \mathrm{HgSO}_{3}$ on

the overall efficienry of three different amounts of heat recovered. $\nabla ; 00 \%, \quad 50 \%, 00 \%$.

RESULTS

Reaction (1)

$$
\begin{aligned}
2 \mathrm{MgO}(\mathrm{s})+\mathrm{SO}_{2}(\mathrm{~g})+x \mathrm{H}_{2} \mathrm{O}(\mathrm{l}) & \\
& 2 \mathrm{SOK}_{\rightarrow} \mathrm{MgSO}_{3} \cdot \mathrm{yH}_{2} \mathrm{O}(\mathrm{s})+(x-\mathrm{v}) \mathrm{H}_{2} \mathrm{O}(\mathrm{l})+\mathrm{HgO}(\mathrm{s})
\end{aligned}
$$

Figure 4 shows the results of bubbling an excess of $\mathrm{SO}_{2}\left(\mathrm{SO}_{2} / \mathrm{MgO}-\mathrm{B}\right)$

through a stirred slurry of $\mathrm{MgO}$ in saturated $\mathrm{MgSO}_{3}$ solution at room

temperature. The $\mathrm{MgO}$ used was formed by decomposition of $\mathrm{MgSO}_{4}$ (reaction (5))

at $1350 \mathrm{~K}$ in a stream of $\mathrm{N}_{2}$ in order to mimic the conditions in the actual

cyrle. The product was removed by filtration in dflute cases and in

concentrated cases it was simply drled before analysis. Identification was by $x$-ray porder diffraction crystallography. In all cases the product was found to 
be $\mathrm{MgSO}_{3} \cdot 6 \mathrm{H}_{2} \mathrm{O}$, except at low $\mathrm{H}_{2} \mathrm{O} / \mathrm{MgO}$ where $\mathrm{MgO}$ remained the dominant phase. The amount of $\mathrm{MgSO}_{3}$ formed was measured by the rmal decomposition and the $\mathrm{SO}_{2}$ evolved estimated by fodimetry. From Fig. 4 it can be seen that in order to have $50 \%$ of $\mathrm{MgO}$ sulfited (that being the necessary amount for the cycle it is required to have about 6 moles $\mathrm{H}_{2} \mathrm{O}$ which is also the necessary amount for hexahydrate formation.

Above $400 \mathrm{C}$, che hexahydrate becomes metastable and the trihydrate is the stable phase (Seidell, 1940). Thus, by carrying this step out at $\geq 400 \mathrm{C}$, the trisulfite will be formed which, preliminary experiments suggest will be adequate hydration for reaction (2) (Mason and Bowman, 1981b). However, as will be seen, more recent experiments do not support this conclusion. Since the reaction is exothermic, heat is produced, resulting in temperoture increase.

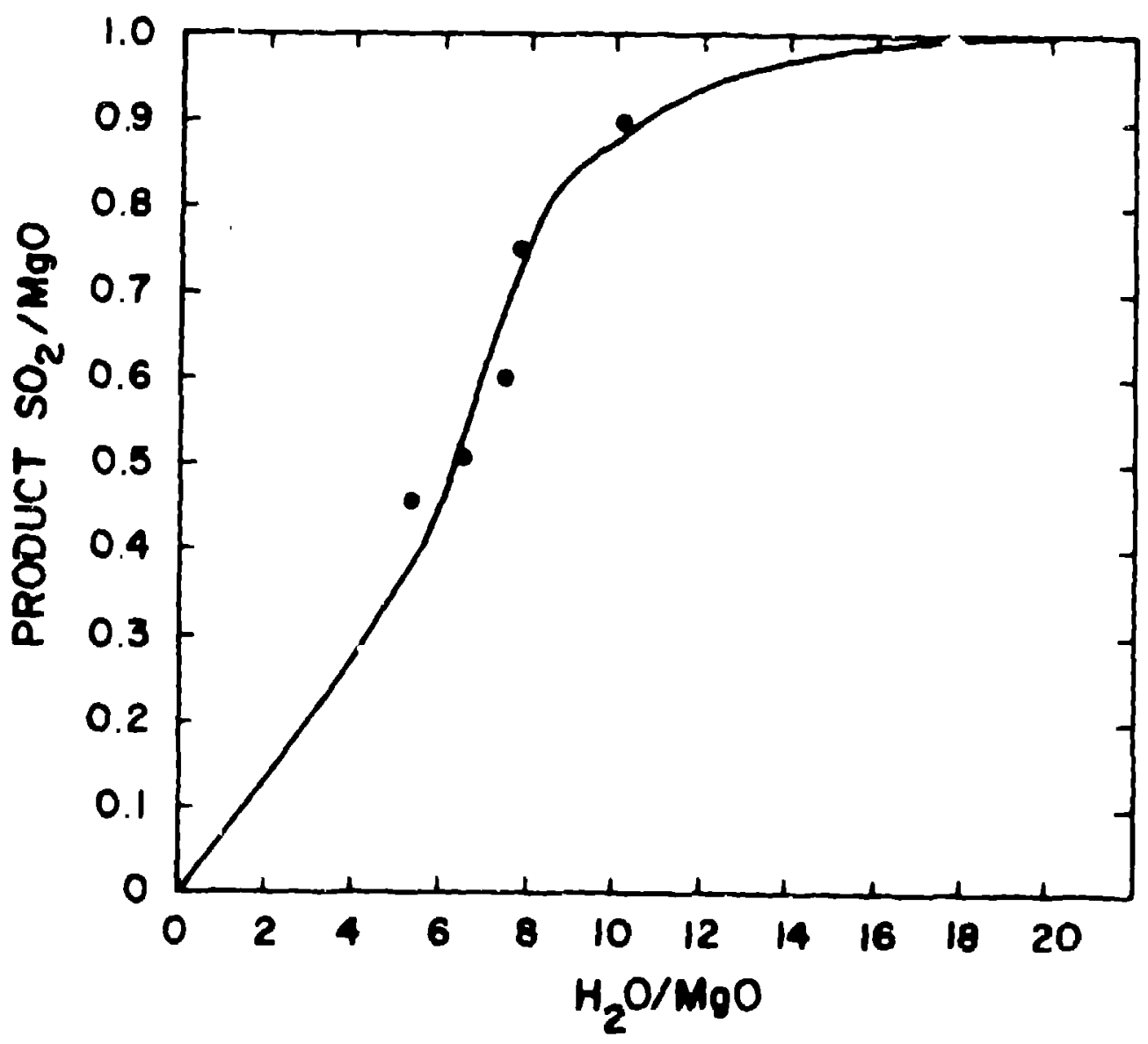

Fig. 4. The amount of MgO sulfitsd as a function of $\mathrm{H}_{2} \mathrm{O}$ present.

Rnaction 2

$\mathrm{MgSO}_{3} \mathrm{YH}_{2} \mathrm{O}(\mathrm{s})+\mathrm{MgO}(\mathrm{s})+\mathrm{I}_{2}(\mathrm{~g}) \longrightarrow \mathrm{MgSO}_{1}(\mathrm{~s})+\mathrm{MgI}_{2}(\mathrm{~s})+\mathrm{yH}_{2} \mathrm{O}(\mathrm{g})$

Previous experiments (Mason and Buwman, 1981b) using a sy'stem where I2 wes possed through a preheated bed of $\mathrm{MgSO}_{3} .6 \mathrm{H}_{2} \mathrm{O}$ and $\mathrm{MgO}$ have establi shed that at $423 \mathrm{~K}, 67 \mathrm{~K}$ of the total possible $\mathrm{MgSO}_{4}$ (based on the stoichiometry) was formed. At this temperature it was estimated that between 2 and 3 moles 01 hydration remained. 
In the present study, a different approach was taken. The reaction was carried out in a teflon cylinder in an evacuated closed pressure vessel which precluded the possibility of removing any reactants or products. The results are shown in Table 1.

In most cases, traces of $\mathrm{Mg}(\mathrm{OH}) \mathrm{I} . \mathrm{H}_{2} \mathrm{O}$ were found (identified by $\mathrm{x}$-ray powder diffraction patterns). The stainless steel vessel was heated to the temperature indicated and maintained there for $40 \mathrm{~min}$. Gas analyses were carried out Doth before and after cooling. The estimation of $\mathrm{MgSO}_{4}$ was carried out gravimetrically and that of $\mathrm{Mgl} 2$ using a specific lodide electrode after removing excess $I_{2}$ and $H I$ by heating the solid product. It can be seen that, the total amount of sulfate formed was $77 \%$. This occurred 1000 higher than in the flow experiments, presumably due to the fact that water vapor was not removed from the reaction site. Palladuim was added as it is known (Takemori, 1978) to catalyze the decomposition of $\mathrm{Hl}$, thereby forcing the preceding equilibria to favor product formation.

Table 1 Results of reacting I2 with $\mathrm{MgSO}_{3} .6 \mathrm{H}_{2} \mathrm{O}$ and $\mathrm{MgO}$ $\mathrm{MgSO}_{3} .6 \mathrm{H}_{2} \mathrm{v}=9.8 \times 10^{-3 M} . \mathrm{MgSO}_{3}: \mathrm{MgO}: \mathrm{I}_{2}=\mathrm{T}: \mathrm{T}: \mathrm{T}$

$\frac{\text { Tempera ture }}{K}$

Products (expressed as a $\%$ of the total possible stoichiometric amount)

\begin{tabular}{llr} 
& $\mathrm{MgSO}_{4}$ & Mg】2 \\
\cline { 2 - 3 } 523 & 54 & 30 \\
523 & 50 & 27 \\
523 & 77 & 24 \\
473 & 54 & 18 \\
423 & 48 & 9 \\
373 & 12 & 4
\end{tabular}

${ }^{1}$ Carried out in presence Pd black, $P d / M g 0=0.1$

The experiments were repeated using the 3-hydrate in place of the 6-hyorate.

These are shown in Table 2 . In ali cases less reaction occurred than previously. Thus experimentally it is shown that for optimal reaction, $y 3$. Since the 3 and 6 hydrates are the known stable hydrates, it oppears that the cycle should be carried out with the 6-hydrate, this being the smallest amount of water which gives acceptable product yields.

TABLE 2 Results of reacting I2 with $19 \mathrm{SSO}_{3} .3 \mathrm{H}_{2} \mathrm{O}$ and $\mathrm{MgO}$ $\mathrm{Mg}+\mathrm{Ju}_{3} \cdot 3 \mathrm{H}_{2} \mathrm{O}=1 . \mathrm{T} \times \mathrm{TO}-2 \mathrm{M}, \mathrm{MgSO}_{3}: \mathrm{MgO}: \mathrm{I}_{2}=\mathrm{T}: \mathrm{T}: \mathrm{T}$

$\frac{\text { Temperature }}{K}$

Products (expressed as : of the total possible stoichtometric amount)

$\underline{\mathrm{MgSO}} 4$

34

523

473

423
28

34
Mgl2

1

1 
Unlike the room temperature aqueous solution rfaction, there is no stoichiometric equivalence between $\mathrm{MgSO}_{4}$ and $\mathrm{MgI}$. This is mainiy due to the concurrent hydrolysis of $\mathrm{MgI}_{2}$ which, at $523 \mathrm{~K}$, was measured to be $44 \%$; and also, in small measure to incomplete hydrolysis:

$$
\mathrm{MgI}_{2}+\mathrm{H}_{2} \mathrm{O}+\mathrm{Mg}(\mathrm{OH}) \mathrm{I}+\mathrm{HI} \text {. }
$$

In addition, it is due to some $\mathrm{H}_{2}$ fomation and furthemore to air oxidation of $\mathrm{MgI}_{2}$ during the removal of $\mathrm{I}_{2}$ and $\mathrm{HI}$ :

$$
2 \mathrm{MgI}_{2}+\mathrm{O}_{2}+2 \mathrm{MgO}+2 \mathrm{I}_{2} \text {. }
$$

There are also some minor side reactions of which the most important is the disproportionation of $\mathrm{MgSO}_{3}$ :

$$
\mathrm{MgSO}_{3}(\mathrm{~s}) \rightarrow 3 / 4 \mathrm{MgSO}_{4}(\mathrm{~s})+\mathrm{MgS}(\mathrm{s}), \Delta \mathrm{H}_{298}=-41.9 \mathrm{~kJ}
$$

which is followed by hydrolysis of Mgs.

$\mathrm{MgS}(\mathrm{s})+\mathrm{H}_{2} \mathrm{O}(1) \rightarrow \mathrm{MgO}(\mathrm{s})+\mathrm{H}_{2} \mathrm{~S}(\mathrm{~g}), \Delta \mathrm{H}_{298}^{\mathrm{O}}=+9.9 \mathrm{~kJ}$

and reaction with $I_{2}$ :

$\operatorname{MgS}(s)+I_{2}(g) \rightarrow M g I_{2}(s)+S(s), \Delta H_{298}^{0}=-74.8 \mathrm{~kJ}$

Although no $S$ was detected, the presence of $\mathrm{CS}_{2}$ and $\operatorname{COS}$ (from the gas analysis) show that it is present at some stage. Worth considering in the same context is the direct oxidation of $\mathrm{MgSO}_{3}$ with $\mathrm{H}_{2} \mathrm{O}$ :

$\mathrm{MgSO}_{3}(\mathrm{~s})+\mathrm{H}_{2} \mathrm{O}(\mathrm{g}) \rightarrow \mathrm{MgSO}_{4}(\mathrm{~s})+\mathrm{H}_{2}(\mathrm{~g}), \Delta \mathrm{H}_{298}^{0}=-34.7 \mathrm{~kJ}$

Althougn this is themodynamically favored, it has never been observed to happen (Mason and Bowian, 1980). It is possible I2 catalyzes this reaction, but it is minor since little $\mathrm{H}_{2}$ is found.

Mass spectrometric gas analyses gave the same general result whe ther the gases were removed before or after coolin; sllowing that there are no significant reactions on cooling. The major constituent was found to be $\mathrm{CO}_{2}(\sim 90$. $2 \times 10-3 M)$ with smali amounts of $\mathrm{CO}(\sim 5 \%), \mathrm{N}_{2}(\sim 2 \%), \mathrm{H}_{2}(\sim 1 \%), \mathrm{CH}_{4}(<1 \%)$. $\mathrm{O}_{2}(<1 \mathrm{C})$ and traces of $\mathrm{CS}_{2}$ and $\mathrm{COS}$.

The formation of $\mathrm{CC}_{2}$ was unexpested and, after further analysis, was found to be due to the contamination of ${ }^{\prime \prime g S O} \mathrm{SO}_{3}$ by $\mathrm{MgCO}_{3}(10 \mathrm{wt}$. \%). The results in Tables 1 and 2 have been corrected to account for this. The temperature is low for $\mathrm{MgCO}_{3}$ decomposition (Stern and Weise, 1969) but apparently suffictent:

$$
\mathrm{MgCO}_{3}+\mathrm{MgO}+\mathrm{CO}_{2}
$$

A possible reaction, forming lu ts

$$
\mathrm{MgSO}_{3}+\mathrm{MgCO}_{3} \rightarrow \mathrm{MgSO}_{4}+\mathrm{MgO}+\mathrm{CO}
$$

Again the temperatire is $10 \mathrm{w},(\Lambda G \leq 0$ at $T=780 \mathrm{k})$. 
A more likely mechanism for $C O$ formation is the water gas reaction:

$$
\mathrm{CO}_{2}+\mathrm{H}_{2} \rightarrow \mathrm{H}_{2} \mathrm{O}+\mathrm{CO}
$$

Hydrogen can also reduce $\mathrm{CO}_{2}$ to $\mathrm{CH}_{4}$ :

$$
\mathrm{CO}_{2}+4 \mathrm{H}_{2} \rightarrow \mathrm{CH}_{4}+2 \mathrm{H}_{2} \mathrm{O}
$$

Consideration of these reactions together with the $\mathrm{H}_{2}$ analysis itself puts an upper limit on the amount of $\mathrm{H}_{2}$ formed based on the initial stoichiometry at $2 \%$. Al though the actual amount of $\mathrm{H}_{2}$ evolved is small, this will be increased with increase in temperature due to large amount (44\%) of $\mathrm{HI}$ formed.

\section{DISCUSSIOII}

The concurrent formation of $\mathrm{MgI}_{2}, \mathrm{HI}$ and $\mathrm{H}_{2}$ shows that reactions 2 ), (3), and (4) ocrur simultaneously and that with increase in temperature (up to $1350 \mathrm{~K}$ for $\mathrm{MgSO}_{4}$ decomposition) amounts of $\mathrm{H}_{2}$ should be obtained up to the equilibrium amount of $\mathrm{HI}$ decomposition corresponding to $77 \%$ formation of $\mathrm{MgSO}_{4}$. Side reactions do occur but these appear to be minimal since no $S$ or $\mathrm{H}_{2} \mathrm{~S}$ vere found al though traces of $\operatorname{COS}$ and $\mathrm{CS}_{2}$ were seen.

The experinentally detemined critical amount of water for high product yield is 6 . This gives an efficiency of $58 \%$ with tota? heat recovery, dropping to $39 \%$ with zero heat recovery. As well as simplicity and relatively ligh efficiency, another advantage this cycle possesses is the lack of corrosivity in the high temperature step which contrasts favorably with those cycles involving sulfuric acid decomposition.

The main drawbacks to tinis cycle 1 nvolve the problems associated with handling solids and the high temperature necessary for decomposing $\mathrm{MgSO}_{4}$. An investigation into high temperature solids handing (Peterson and Bowman, 1930) has shown that some sulfate decompositions, most notably $\mathrm{Bi}_{2}\left(\mathrm{SO}_{4}\right)_{3}$ and $\mathrm{ZnSO}_{4}$, take place rapidily indicating heat transfer to and from the solid is also rapid.

Since $t_{t}$ is possible that $1350 \mathrm{~K}$ may be an unrealisticaily high temperature for avallable heat, we carried out a search for alternative metals which $f^{3} t$ the following criteria:

a) sulfate must decompose in the temperature range availalbe $(<1300 k)$,

b) iodide must hydrolyze easily, and

c) salts mu'st not be rare, toxic, or expensive.

Two metals fit these criteria, they are lanthanum and titanium. For lanthanum, the trilodide hydrolyzes readily only as far as the oxyiodide and lanthanum trisulfate decomposes to lanthanum dioxymonosulfate at $1270 \mathrm{~K}$. For titanium, in the tetravalant state, the fodide will be in the lquid or vapor phases (mp 423 $K$, bp $650 \mathrm{~K}$ i and hydrolyzes to $\mathrm{THO}_{2}(\Delta \mathrm{GO}=0$ at $430 \mathrm{~K}$ ). Titanium sulfate is reported to decompose to $\mathrm{TiO}_{2}$ and $\mathrm{SO}_{3}$ at $870 \mathrm{~K}$ (Stern and Wetse, 1966).

\section{CONCLUSION}

The $\mathrm{MgSO}_{3} / \mathrm{Mgl}_{2}$ cycle has been shown experimentaily to require minimal amounts of water for high yields of reaction products. It therefore opens up new possibilities in thermochemical $\mathrm{H}_{c}$ cycles where effictencies wtil be nigher due to the elimination of solution chemistry. 


\section{ACKNOWLEDGEMENTS}

We wish to thank Terry Wallace for support and interest, Wesley jones and Ed Onstott for useful discussions, Mary Pretzel for obtaining and reading the $x$-ray diffraction photographs, Nancy Koski for gas analyses and Mike Fletcher for $\mathrm{MgSO}_{3}$ analysis.

Besenbruch, G. E., K. H. McCorkle, J. H. Norman, D. R. O'Keefe, J. R. Schuster, M. Yoshimoto (1980). Hydrogen production by the GA sulfur-iodine process. A progress report. Proc. 3rd World $\mathrm{H}_{2}$ Energy Conf., 1, 243-256.

Bownan, M. G. $(1980)$. Interfacing primary heat sources and cycles for thermochemical hydrogen production. Proc. 3rd World H2 Energy Conf.., 1, 335-344.

Ducarroir, M., M. Tmar ąnd C. Bernard (1980). Possibilités de stockage de l'énergie solaire a partir de sulfates. Revue Phys. Appl., 15, 513-528.

?unk, I. E., and R. M. Reinstrom (1966). Energy requiremerits in the production of $\mathrm{H}_{2}$ from water. I and EC Process Design and Development, $5,336-342$.

Lau, K. H., D. Cubbiciotti and D. L. Hildenbrand (1977). Effusion studies of the thermal decomposition of magnesium and calcium sulfates. J. Chem. Phys., 66, $4532-4539$.

Mason, C. F. V. and iA. G Bowman (1980). Metal sulfite/sulfate reactions in the rmochemical $\mathrm{H}_{2}$ cycles. Proc. 3rd Technical Workshop of The rmochemcial Processes, 198-201 (LAUR-80-1611).

Mason, C. F. V. and M. G. Bowman (1981a). The oxidation of metal sulfites by iodine for use in thermochemical $\mathrm{H}_{2}$ cycles. Proc. 4th Techrical Workshop on Thenmochemical Processes (LAUR-81-2477).

Mason, C. F. V. and M. G. Bowman (1981b). Improved effficiency in the sulfur dioxide-indine cycle through the use of magresium oxide. Proc. 16th IECEC, 2, $1411-1414$

Mizuta, S., Y. Oosawa, W. Mondo and T. Kumagai (1980). Addition of magnesiun ion for the separation of $\left(\mathrm{HI}_{-} \mathrm{H}_{2} \mathrm{SO}_{4}\right)$ mixture. Private conmunication.

Nurman, J. H., K. J. Mysels, R. Sharp and D. G. Willianson (1980). Studies of the sulfur-iodine thermochemical water-splitting cycle. Proc. 3rd World $\mathrm{H}_{2}$ Energy Conf., 1, 257-275.

Parker, V. B., D. D. Wayman and W. H. Evans (1971). Selected Values of Cremical Thermodynamic Properties. NBS Technical Note 270-6.

Peterson, C. L. and M. G. Bowman (1980). Solids decomposition kinetics for LASL bismuth sulfate cjecle. Proc. 15th IECEC.. 3, 2289-2292.

Seidel1, A. (1940). Solubitities of Organic and Metal Organic Compounds, D. Van Nostrand, New York.

Stern, K. H. and E. L. Weise (1966). High Temperature Properties and Decomposition of Inorganic Salts, Part T, Sulfates, NSRDS-NBST.

Stern, K. H. and E. L. Weise (1969). High Temperature Properties and Decomposition of Inorganic Salts. Part 2 Carbonates. NSRDS-NES30.

Takemori. Y. (1978). Decomposition of hydrogen iodide. Proc. Ist Technical Workshop on Themochemical Processes. 155-178.

Van Velzen, D. and $H$. Langenkamp (1980). Status report on the operation of the production by the mark-13 process. Proc. 3rd World $\mathrm{H}_{2}$ Energy Conf.., I, $423-438$.

Weast, R. C. (ed.) (1974). Handbook of Chemistry and Pliysics. CRC Press. 